\title{
Constraints Faced by the Extension Personnel Working in State Agriculture Department of Marathwada Region
}

\author{
A.M. Kshatriya* and P.R. Deshmukh \\ Department of Extension Education, VNMKV, Parbhani (M.S.), India \\ *Corresponding author
}

\section{A B S T R A C T}

Keywords

Extensional personnel, Constraints, State agriculture department

Article Info

Accepted:

10 November 2019

Available Online:

10 December 2019
The present study was conducted in Parbhani and Nanded district of Marathwada region in Maharashtra state. Out of eight district of Marathwada, Nanded and Parbhani district were selected randomly for the study. The all 25 taluka from Nanded and Parbhani district was selected randomly for the present study. Thus of 236 extension personnel from Parbhani and Nanded district were selected by One third (1/3) of proportionate random sampling method. i.e. The description of respondents is out of 24 Taluka agriculture officer only 8, out of 31 Circle Agriculture Officer only 10 out of 107 Agriculture supervisor only 36 and out of 545 Agriculture Assistants only 182 was selected from total 708 Extension Personnel working in state Agriculture Department. 94.92 per cent of the extension personnel reported that lack of equipments, infrastructure and other necessary resources and its rank while I, 88.56 per cent of the extension personnel reported that lack of recognition and its rank II.

\section{Introduction}

Agriculture department considers farmer as the focal point and the whole department is organized in such a fashion that a single mechanism is working to facilitate the farmer for adoption of advanced technology and sustainable use of available resources.

To study the job stress of extension personnel working in state agriculture department is essential to analyze their stress level. Job perception of employee is generally how they feel about different aspects of their jobs, extent to which they like or dislike their jobs and also considered as a strong predictor of overall individual well-being as well as a good predictor of intentions or decisions of teachers to leave their job.

Job performance of the employee is another criterion for evaluating the effectiveness of an 
organization. Job satisfaction of employee is another criterion for evaluating the effectiveness of an organization. Greater satisfactions lead in a simple or direct way to superior performance Job stress is described as the psychological strain or distress that arises from individual or organizational stressors in the workplace.

\section{Materials and Methods}

The present study was conducted in Parbhani and Nanded district of Marathwada region in Maharashtra state. Out of eight district of Marathwada, Nanded and Parbhani district were selected randomly for the study. The all 25 taluka from Nanded and Parbhani district was selected randomly for the present study. The extension personnel i.e. Agriculture Assistant at village level, Circle Agriculture Officer at circle level, Taluka Agriculture Officer at taluka level were considered. Thus of 236 extension personnel from Parbhani and
Nanded district were selected by One third (1/3) of proportionate random sampling method. Ex-post factor research design was adopted in this study. The data were collected with the help of pretested interview schedule. The statistical methods and tests such as frequency, percentage, mean, standard deviation, co-efficient of correlation, multiple regressions and path analysis were used for the analysis of data.

\section{Results and Discussion}

Constraints faced by the extension personnel working in state agriculture department

The schedule covered possible constraints which may hinder extension personnel working in state agriculture department. Were included in the schedule and the responses were given form the extension personnel and the details were enlisted in the Table 1.

Table.1 Constraints faced by extension personnel working in state agriculture department

\begin{tabular}{|c|c|c|c|c|}
\hline $\begin{array}{c}\text { Sr. } \\
\text { No. }\end{array}$ & Constraints & No. & $\mathbf{( \% )}$ & Rank \\
\hline $\mathbf{1 .}$ & Lack of equipments, infrastructure and other & 224 & 94.92 & I \\
\hline $\mathbf{2 .}$ & necessary resources & & & \\
\hline $\mathbf{3 .}$ & Handling multiple schemes at a time is difficult. & 182 & 77.12 & V \\
\hline $\mathbf{4 .}$ & Number of meetings in a month & 152 & 64.41 & IX \\
\hline $\mathbf{5 .}$ & Lack of recognition & 209 & 88.56 & II \\
\hline $\mathbf{6 .}$ & Lack of trained and skilled staff & 173 & 73.31 & VI \\
\hline $\mathbf{7 .}$ & Lack of rewards, promotion and incentives & 194 & 82.20 & III \\
\hline $\mathbf{8 .}$ & Lack of co-operation from Co-workers & 189 & 80.08 & IV \\
\hline $\mathbf{9 .}$ & Heavy workload due to less employees & 176 & 74.58 & VII \\
\hline $\mathbf{1 0 .}$ & Lack of transport facilities & 141 & 59.75 & X \\
\hline $\mathbf{1 1 .}$ & Lack of skilled orientation training & 138 & 58.47 & XI \\
\hline $\mathbf{1 2 .}$ & More non technical work & 165 & 69.92 & VIII \\
\hline $\mathbf{1 3 .}$ & No good road facilities to access with village & 117 & 49.58 & XIII \\
\hline & & 123 & 52.12 & XII \\
\hline
\end{tabular}


It was observed from Table 1 that, 94.92 per cent of the extension personnel reported that lack of equipments, infrastructure and other necessary resources and its rank while I, 88.56 per cent of the extension personnel reported that lack of recognition and its rank II, 82.20 per cent of the extension personnel reported that lack of rewards, promotion and incentives provided and its rank III, 80.08 per cent of the extension personnel reported that lack of cooperation from co-workers and its rank IV, 77.12 per cent of the extension personnel reported that handling multiple schemes at time is difficult and its ranks V, 73.31 per cent of the extension personnel reported that lack of trained and skilled staff and its rank VI, which were the major constraints found during course of investigation. Whereas, the Heavy workload due to fewer employees (74.58\%) was ranked VII, followed by more non technical work is there $(69.92 \%)$ ranked VIII, number of meetings more in a month $(64.41 \%)$ ranked IX, lack of transport facilities $(59.75 \%)$ ranked $X$. as these constraints are responsible for job stress of extension personnel.

In other constraints lack of skilled orientation training $(58.47 \%)$ was ranked XI followed by lack of stress management training program for all employees (52.12) was ranked XII, no good road facilities to assess with village $(49.58 \%)$ ranked XIII.

\section{Implication}

Regarding the constraints faced by extension personnel, it suggested that state department of agriculture should provide the equipments, infrastructure, adequate transport facilities and other necessary resources in abundant manner by agriculture department for further good work. Extension personnel should involve in different developmental activities for better co-operation and performing good work.

\section{References}

Aimable, R. (2011). An analysis of Job perception and Job performance in the University of Agricultural Sciences, Bangalore, M. Sc. (Agri.), Thesis (Unpub.), University of Agricultural Sciences, Bangalore.

Nisha, P. R. And Sudeepkumar, N. K., 2011, Constraints faced by the veterinary teaching faculty. Tamil Nadu J. Veter. Animal Sci., 7(1): 16-22

Nwalieji H. U.N, Igbokwe E. M. And Okeke M. N. (2013). Constraints to local Government performance in agricultural development in Anambra state. Nigeria. J. Agric. Extn., 17(2): 88-97.

Goldi, Tewari. (2014). Academic Performance of the Students (APS) in Undergraduate Degree Program: Perception of Stakeholders at University of Agricultural Sciences, Bangalore, M. Sc. (Agri.), Thesis (Unpub.), University of Agricultural Sciences, Bangalore.

\section{How to cite this article:}

Kshatriya, A. M. and Deshmukh, P. R. 2019. Constraints Faced by the Extension Personnel Working in State Agriculture Department of Marathwada Region. Int.J.Curr.Microbiol.App.Sci. 8(12): 900-902. doi: https://doi.org/10.20546/ijcmas.2019.812.115 